\title{
The place of indirect venography tests after pulmonary computed tomography angiography in the diagnosis of pulmonary thromboemboli
}

\author{
Oguzhan Karaoglu ${ }^{1}$, Kemal Can Tertemiz ${ }^{2}$, Erkan Yilmaz ${ }^{1}$, Atila Akkoclu ${ }^{2}$, Neşat Çullu ${ }^{3}$, Cenk Elibol ${ }^{1}$, \\ Funda Dinc Elibol ${ }^{1}$
}

${ }^{1}$ Department of Radiology, Faculty of Medicine, Dokuz Eylül University, İzmir, Turkey

${ }^{2}$ Department of Pulmonology, Faculty of Medicine, Dokuz Eylül University, İzmir, Turkey

${ }^{3}$ Department of Radiology, Faculty of Medicine, Muğla Sıtkı Koçman University, Muğla, Turkey

Kardiochirurgia i Torakochirurgia Polska 2014; 11 (4): 445-451

\begin{abstract}
Aim: To investigate the effectiveness of indirect computed tomography (CT) venography applied after pulmonary CT angiography to patients with suspected pulmonary embolism.

Material and methods: The study comprised 80 patients at high/moderate risk of pulmonary embolism (PE) according to the clinical findings. Computed tomography venography (CTV) was performed 3-3.5 minutes after taking pulmonary CTA images. Color Doppler ultrasonography (CDUS) of the lower extremities was applied to all patients before pulmonary CTA or within 24 hours after CTA.

Results: Pulmonary embolism was determined in a total of 19 patients (23\%). Six patients had deep venous thrombosis on CTV examination even though the CDUS findings were normal. Accepting color Doppler ultrasonography findings as the gold standard, the sensitivity of CTV in determining deep vein thrombosis (DVT) was found to be $100 \%$, specificity $91 \%$, positive predictive value $60 \%$, negative predictive value $100 \%$, likelihood of giving a positive result 11.1, and likelihood of giving a negative result 0 . There was a statistically significant good degree of correlation between the two methods $(r=0.741$, $p<0.001$ ).

Conclusions: Computed tomography venography examination applied after pulmonary CTA is a fast imaging technique that has high diagnostic value and can be an alternative to CDUS, especially when CDUS is insufficient in application and evaluation.
\end{abstract}

Key words: pulmonary embolism, venous thrombosis, CT angiography.

\section{Introduction}

Pulmonary embolism (PE) is a frequently seen condition, which is difficult to diagnose and treat and has high

\section{Streszczenie}

Cel: Ocena efektywności pośredniej wenografii tomografii komputerowej (computed tomography venography - CTV) stosowanej po płucnej angiografii tomografii komputerowej (computed tomography angiography - CTA) u pacjentów z podejrzeniem zatoru płucnego.

Materiał i metody: Badaniem objęto 80 pacjentów obarczonych wysokim lub średnim ryzykiem zatoru płucnego wg orzeczeń klinicznych. Wenografię tomografii komputerowej przeprowadzano 3-3,5 minuty po zrobieniu zdjęć CTA. U wszystkich pacjentów kolorową ultrasonografię dopplerowską (color doppler ultrasonography - CDUS) dolnych kończyn wykonywano przed płucnym badaniem CTA lub w ciągu 24 godzin od CTA. Wyniki: Zator płucny stwierdzono u 19 pacjentów (23\%). U 6 pacjentów badanie CTV wykazało zakrzepicę żył głębokich, mimo że wyniki CDUS były prawidłowe. Przyjmując wyniki CDUS jako złoty standard, określono czułość CTV w diagnozowaniu zakrzepicy żył głębokich na 100\%, swoistość - 91\%, dodatnią wartość predykcyjną - 60\%, ujemną wartość predykcyjną - 100\%, prawdopodobieństwo wyniku dodatniego - 11,1\%, a prawdopodobieństwo wyniku ujemnego - 0\%. Stwierdzono statystycznie znamienny, dobry stopień korelacji pomiędzy obiema metodami $(r=0,741 p<0,001)$.

Wnioski: Badanie CTV przeprowadzone po płucnym badaniu CTA jest szybką techniką obrazowania o wysokiej wartości diagnostycznej, która może służyć jako alternatywa dla badania CDUS, szczególnie gdy to ostatnie okazuje się niewystarczające.

Słowa kluczowe: zatorowość płucna, zakrzepica żył, angiografia TK.

mortality [1]. In most patients, PE is not seen in isolation, but develops as a complication of deep vein thrombosis (DVT) in the lower extremities [2]. There is current wide-

Address for correspondence: Neşat Çullu, Muğla Sıtkı Koçman Üniversitesi Tıp Fakültesi, 48000 Muğla, Turkey, phone: +905072030472, e-mail: nesatcullu77@gmail.com 
spread use of computed tomography angiography (CTA) in the diagnosis of PE and the first and basic images of Color Doppler ultrasonography (CDUS) in determining DVT [3-5].

Tab. I.

A. Wells score

\begin{tabular}{lc}
\hline Most likely diagnosis of PE & 3 \\
\hline DVT examination findings & 3 \\
\hline History of DVT or PE & 1.5 \\
\hline Heart rate >100/min & 1.5 \\
\hline Surgery/immobilization within last 4 weeks & 1.5 \\
\hline Received cancer treatment within last 6 months & 1 \\
\hline Hemoptysis & 1 \\
\hline $\begin{array}{l}\text { Clinical probability: 0-1 (low), 2-6 (moderate), 7 (high), } \\
<4 \text { (unlikely) > 4 (likely) }\end{array}$ \\
\hline PE - pulmonary embolism, DVT - deep vein thrombosis
\end{tabular}

B. Geneva score

\begin{tabular}{ll}
\hline Recent surgery & 3 \\
\hline History of PE or DVT & 2 \\
\hline $\mathrm{PaO}_{2} \mathrm{mmHg}$ & 4 \\
\hline$<48.7$ & 3 \\
\hline $48.7-59.9$ & 2 \\
\hline $60-71.2$ & 1 \\
\hline $71.3-82.4$ & 2 \\
\hline PaCO ${ }_{2} \mathrm{mmHg}$ & 1 \\
\hline$<36$ & 2 \\
\hline $36-38.9$ & 1 \\
\hline Age & 1 \\
\hline$>80$ & 1 \\
\hline $60-79$ & 1 \\
\hline Heart rate $>$ 100/min & \\
\hline Atelectasis & \\
\hline Hemidiaphragm elevation & \\
\hline Clinical probability: 0-4 (low), 5-8 (moderate), >9 (high) \\
\hline PE - pulmonary embolism, DVT - deep vein thrombosis \\
C. Miniati method
\end{tabular}

Main symptoms: sudden onset dyspnea, chest pain, syncope

\begin{tabular}{l}
\hline High clinical probability \\
\hline At least 1 of the 3 main symptoms and/or \\
\hline At least 2 of: raised right heart ECG findings \\
\hline Oligemia radiologically \\
\hline Hilar artery amputation or infarct \\
\hline Moderate clinical probability \\
\hline 1 of the 3 main symptoms but with no additional radiological or \\
ECG findings \\
\hline Low clinical probability \\
\hline None of the 3 main symptoms or these symptoms can be expla- \\
ined as the findings of a different diagnosis such as COPD, pneu- \\
monia, pulmonary edema, myocardial infarct, or pneumothorax. \\
\hline ECG - electrocardiography
\end{tabular}

In recent years, in CTA applied to patients for PE, the venous structures below the level of the diaphragm are evaluated from the obtained CT slices after waiting a certain time. By this method of indirect CT venography (CTV), thromboses in the deep venous system causing PE can be examined immediately after pulmonary CTA without any need for the use of additional contrast materials [2, 6].

The aim of this study was to investigate the efficacy of CTV imaging of lower extremity DVT, applied following pulmonary CTA, in patients clinically evaluated at high/moderate risk of $\mathrm{PE}$ and to compare it to CDUS.

\section{Material and methods \\ Study population}

The study comprised 80 patients (42 males, mean age 58 years; 38 females, mean age 63 years) who were directed to the Radiology CT Unit for a pulmonary CTA test, having been clinically evaluated as being at high/moderate risk for PE between November 2006 and July 2007. The clinical potential of all patients had been calculated by the Chest Diseases Department according to the methods and scales defined below (Table I). The study consisted of patients with a score of at least one high/moderate clinical probability.

\section{Examination technique}

\section{Ultrasonography technique}

Lower extremity CDUS examination was made of all patients before or within 24 hours after pulmonary CTA. By evaluating the lower extremity deep venous system in respect of DVT from both main femoral veins to the level of distal popliteal trifurcation, the age and anatomic location of any thrombus present was reported.

In the first stage, the wall structure of the veins, the echogenicity in the lumen, the vein diameter, response to compression and respiratory diameter changes were evaluated with gray scale ultrasonography. In the second stage, the color filling and flow forms were evaluated with CDUS. Diagnosis of thrombus was made from direct visualization of the thrombus in the lumen, and absence of or reduced response to compression. Auxiliary diagnostic criteria were defined as vascular response to augmentation, color filling and spectral flow forms (Fig. 1C). All the ultrasonographic examinations were performed using an HDI 5000 and 11 (ATL, Bothell, ABD) ultrasonography device with advanced technology properties of high resolution and a wide band 7-12 MHz probe. The CDUS examination was evaluated by a senior radiology assistant with at least one year's experience.

\section{Computed tomography venography technique}

The CT tests were performed in the radiology unit with a 4-channel multidetector M8000 CT device (Philips, Holland). Before the CT examination, a vein in the forearm of all patients was opened with an 18-20 G catheter and 120-140 ml of non-ionic contrast dye was administered at $4 \mathrm{ml} / \mathrm{s}$ with an automatic injector. After injection of the 

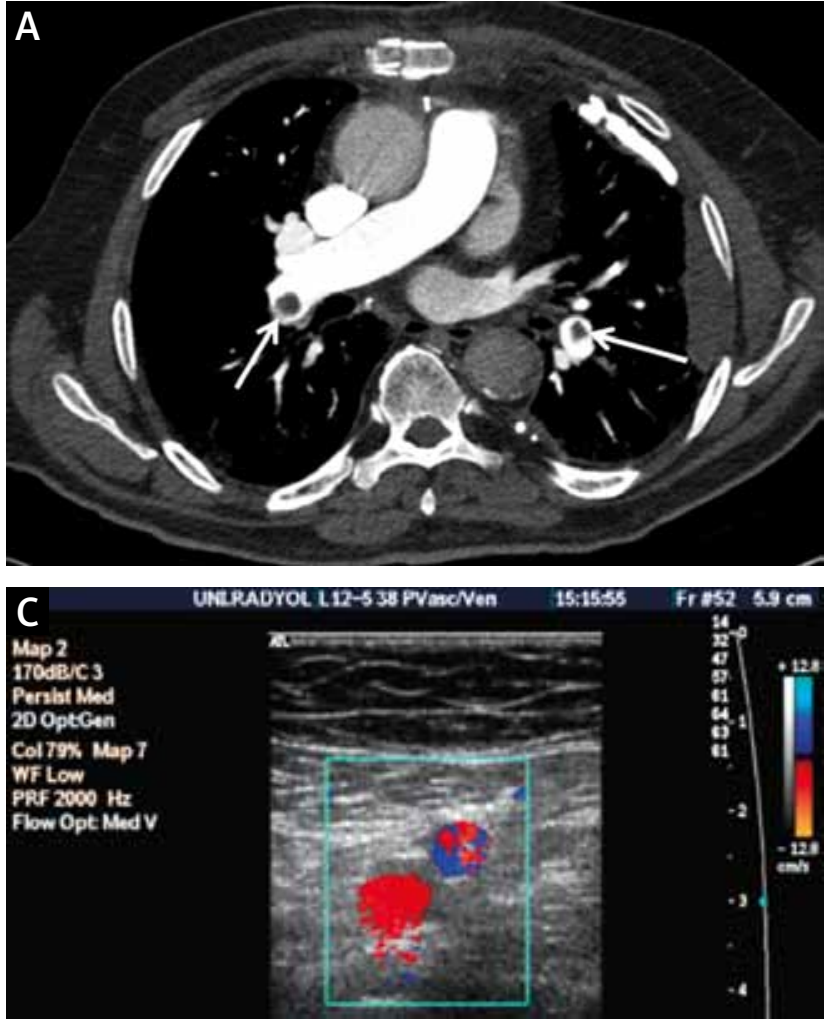

contrast dye, taking of the slices was started with a 15-20 second delay.

During the examination, the patients were instructed to hold their breath. The examination was made with the patient in a supine position, and to prevent subclavian vein compression, the arm into which the injection had been made was held at the side and the other arm at the level of the head. Images were taken at 1.5 pitch value and $1.3 \mathrm{~mm}$ slice thickness from the apex of the lungs to the level of the diaphragm. Dosage parameters of 120-150 kVp and 350$400 \mathrm{~mA}$ were used depending on the weight of the patient. The CTA test of the lower extremity area from the iliac crest to the distal third of the leg was made 3-3.5 minutes after the CTA images were taken. During this procedure additional contrast dye was not used. The CTV images were obtained in a caudo-cranial direction at $7.5 \mathrm{~mm}$ slice thickness and 1.5 pitch value.

\section{Computed tomography venography evaluation}

Evaluation of pulmonary CTA was performed by a specialist radiologist and a final year radiology assistant, each without any knowledge of the other. Cases which were evaluated differently were again discussed and a consensual agreement was made. The observation of a hypodense filled defect within the vein on consecutive CTV slices (Fig. $1 \mathrm{~A}$ and $2 \mathrm{~A}$ ) was accepted as a direct diagnostic criterion for DVT (Fig. 1B, 2B and 2C). Auxiliary diagnostic criteria were venous widening, infiltration in the perivenous fat tissue, and lack of wall and segmental staining [2]. According to these criteria, the presence and location of DVT were defined.

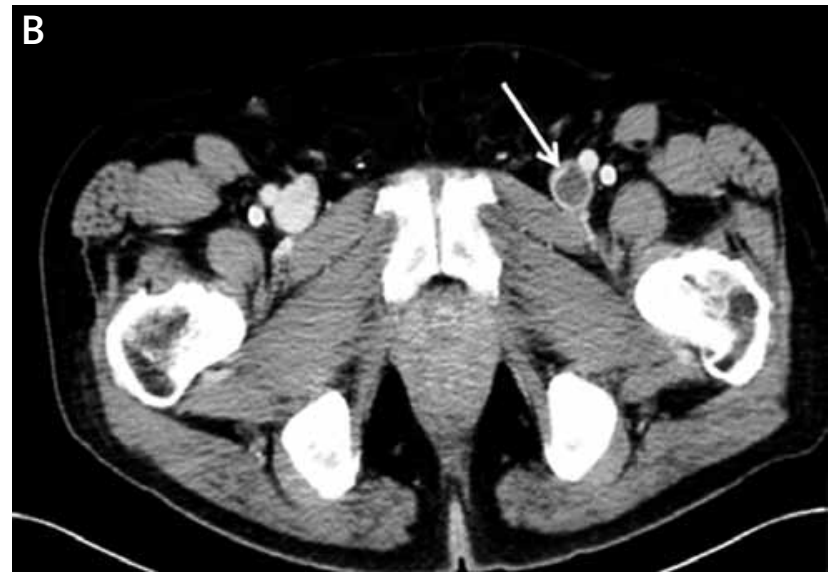

Fig. 1. Patient at high risk of pulmonary embolism (PE) according to the Well clinical classification. A) Segmental PE observed in the inferior lobe pulmonary artery bilaterally on pulmonary computed tomography angiography (CTA) (white arrows). B) Increased diameter in the proximal left main femoral vein and thrombus observed on the slice passing from the proximal thigh (white arrows). C) Thrombus was not observed in this area on color Doppler ultrasonography (CDUS)

\section{Statistical analysis}

Accepting the CDUS results as the gold standard, they were compared with the CTV results. The values of sensitivity, specificity, accuracy, positive predictive value, negative predictive value, likelihood of giving a true positive result and likelihood of giving a true negative result were calculated. To determine the correlation between the CDUS results and the CTV results, the Spearman correlation test was performed using SPSS (version 11.0) software.

\section{Results}

The study comprised 80 patients of whom 42 (52\%) were male with a mean age of 58.38 years and 38 (48\%) were female with a mean age of 63 years. In the pulmonary CTA test, PE was determined in 19 (23\%) patients. According to the Well clinical classification, PE was determined in $6(60 \%)$ of 10 high clinical probability patients, in the Geneva clinical classification, in 1 (17\%) of 6 high clinical probability patients, and in the Miniati clinical classification, in 6 (67\%) of 9 high clinical probability patients. Deep vein thrombosis and/or PE were not determined in any patient defined as being at low risk of possible PE in more than one clinical classification. The distribution of PE clinical probability according to the clinical classifications is shown in Table II.

According to the pulmonary CTA findings, a total of 110 (62\%) images of total, partial and subsegmental filled defects in the lumen thought to be consistent with PE were observed in the right lung and 67 (38\%) in the left lung (Table III). In both lungs the most frequently observed segment with PE findings was the anterior lobe posterobasal 

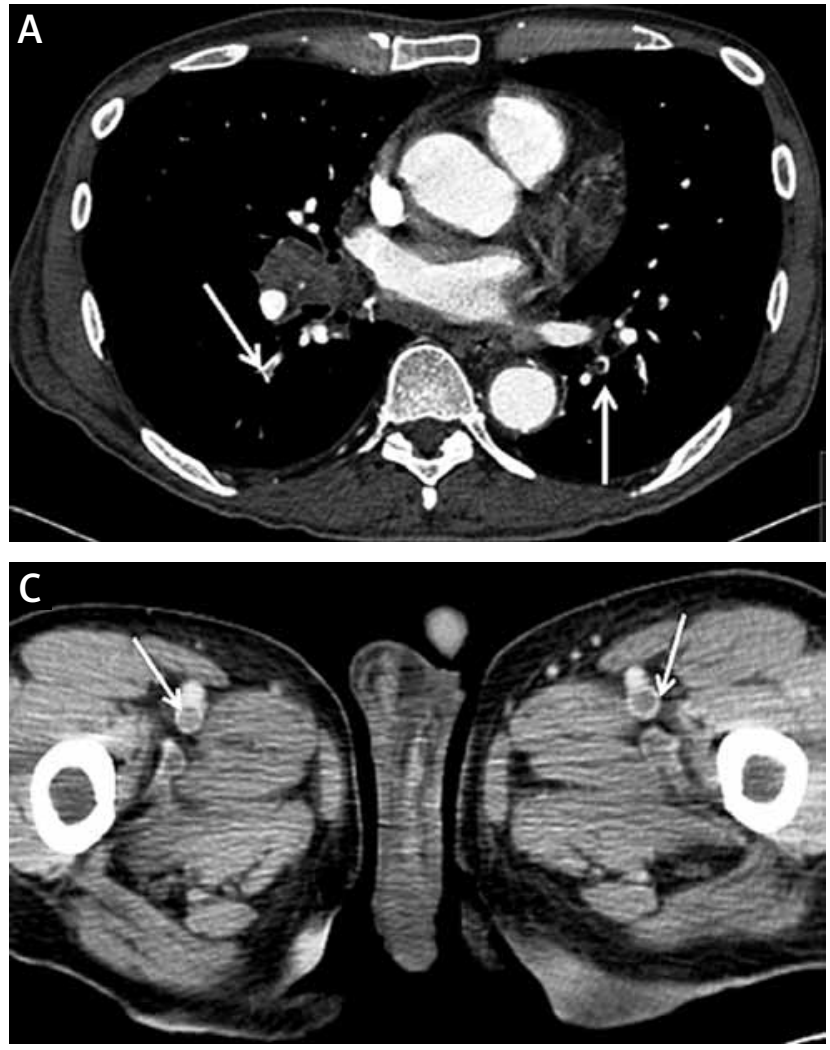

Tab. II. Pulmonary embolism risk distribution according to clinical classification

\begin{tabular}{llccc} 
& & \multicolumn{3}{c}{ Clinical classification } \\
\cline { 2 - 5 } $\begin{array}{l}\text { Clinical } \\
\text { probability }\end{array}$ & Wells & Geneva & Miniati \\
\cline { 2 - 5 } & Moderate & $10(6)$ & $6(1)$ & $9(6)$ \\
\cline { 2 - 5 } & Low & 41 & $36(9)$ & $36(11)$ \\
\cline { 2 - 5 } & & $30(19)$ & $80(19)$ & $35(2)$ \\
\hline
\end{tabular}

Number of patients (number of patients with PE).

segment at $21(19 \%)$ in the right lung and $14(16 \%)$ in the left lung.

The CTV and CDUS results of the patients were compared for evaluation (Table IV). According to this, 9 patients were diagnosed with DVT from both CTV and CDUS. In 6 patients with normal CDUS examination results, findings of DVT were seen on CTV. It was noted that of the 6 patients diagnosed with DVT from CTV, which was not observed on CDUS, PE was present in 5 patients. Of these patients, 1 was wearing a plaster cast, 1 was seriously obese and 1 had evident edema in both legs.

The evaluation of the comparison of CTV test results when CDUS was taken as the clinical gold standard is shown in Table V. To determine the correlation between the CDUS results and the CTV results, the Spearman correlation test was performed using SPSS (version 11.0) software. A significant level of correlation was observed $(r=0.741, p<0.001)$.

The results of the comparison of the CTA and CTV tests are shown in Table VI. In 11 patients determined with PE in

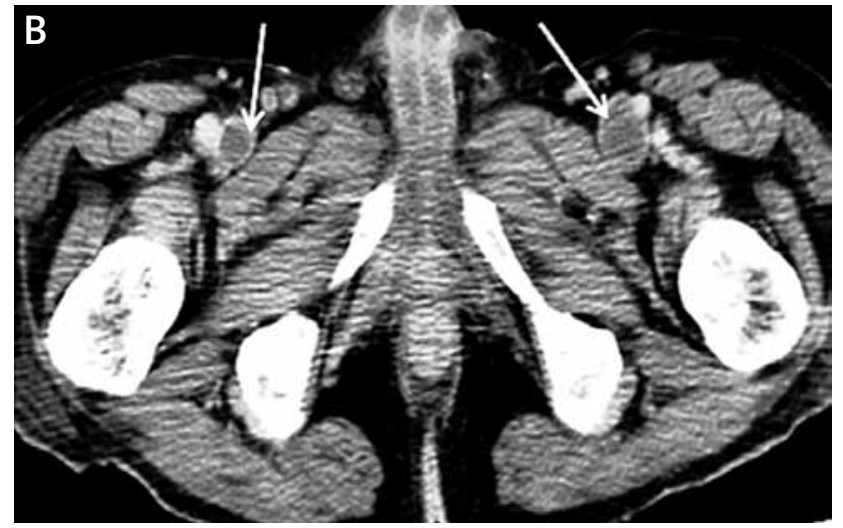

Fig. 2. Patient at high risk of pulmonary embolism (PE) according to the Wells and Miniati clinical classifications. A) Segmentally filled defects (white arrows) observed in the inferior lobe pulmonary artery bilaterally on pulmonary computed tomography angiography (CTA). Thrombus seen bilaterally extending from the proximal main femoral vein as far as the distal popliteal vein on the computed tomography venography (CTV) slices at the pelvic level. Thrombus was determined on color Doppler ultrasonography (CDUS) examination at the level of (B) the main femoral vein (white arrows) and (C) the main femoral vein bifurcation (white arrows)

CTA, DVT was found in the CTV examination. There was PE in 4 patients where DVT was not determined by either imaging method. In 8 patients where DVT was not seen with either CTV or CDUS, PE was determined with CTA.

The CTV and CDUS evaluations separately examined the pelvic, above-the-knee, popliteal and crural areas (Table VII). In respect of DVT, while positive findings were determined on CTV in the pelvic and crural veins in 3 and 7 patients respectively, thrombus was observed in only 1 patient with CDUS. In both examinations, findings of DVT were most often in the above-the-knee location (CTV, 12 patients; CDUS, 8 patients). With CTV thrombus was encountered the least frequently in the pelvic area.

When thoracic findings from pulmonary CTA apart from PE were evaluated (Table VIII), the most commonly determined pathologies were pleural effusion and chronic obstructive pulmonary disease (COPD). There were findings of pleural effusion in 8 patients and of COPD in 1 of the 19 patients with PE. Pulmonary infarct was determined in 7 patients.

\section{Discussion}

Nowadays, there is increasing application of CTA and lower extremity CTV testing in the same session [9]. In this method, known as combined CTA and CTV, following pulmonary CTA applied for PE, 3-5 min after starting the injection of contrast dye, the venous system between the diaphragm and the popliteal area is scanned at $5-10 \mathrm{~mm}$ slice thickness and $1-5 \mathrm{~cm}$ slice intervals $[2,6]$. Different studies 
Tab. III. Vascular location of pulmonary embolism according to pulmonary computed tomography angiography findings

\begin{tabular}{|c|c|c|}
\hline Main pulmonary artery & $\begin{array}{c}\text { Right } \\
3(+), 2(++)\end{array}$ & $\begin{array}{c}\text { Left } \\
1(+), 2(++)\end{array}$ \\
\hline \multicolumn{3}{|l|}{ Superior lobe artery } \\
\hline Apical(R)/apicoposterior(L) & $3+, 3 \ddagger$ & $1++, 1+, 2 \ddagger$ \\
\hline Anterior (R/L) & $3+, 2 \ddagger$ & $1++, 3+, 4 \neq$ \\
\hline Posterior (R) & $1++, 2+, 2 \ddagger$ & \\
\hline Lingula (L) & & $3++, 1+, 2 \ddagger$ \\
\hline \multicolumn{3}{|l|}{ Subsegmental arteries } \\
\hline \multicolumn{3}{|l|}{ Middle lobe artery (R) } \\
\hline Medial (R) & $1++, 4+, 1 \neq$ & \\
\hline Lateral (R) & $2++, 3+, 2 \ddagger$ & \\
\hline Subsegmental arteries & & \\
\hline
\end{tabular}

\section{Inferior lobe artery}

\begin{tabular}{lcc}
\hline Superior (R, L) & $3++, 5+, 3 \ddagger$ & $1++, 5+, 2 \ddagger$ \\
\hline Medial basal (R) & $4++, 6+, 5 \ddagger$ & \\
\hline Lateral basal (R, L) & $3++, 7+, 7 \ddagger$ & $2++, 6+, 4 \ddagger$ \\
\hline Posterior basal (R, L) & $2++, 10+, 9 \ddagger$ & $1++, 7+, 6 \ddagger$ \\
\hline Anterior basal (R) & $1++, 7+, 4 \ddagger$ & \\
\hline
\end{tabular}

Anteromedial basal (L) 6+, 6‡

Subsegmental arteries

+- partial thrombus, ++- total thrombus, $\ddagger-$ subsegmental branch thrombus, $R$ - right, L - left

Figures show the number of cases with findings of partial/total/subsegmental branch emboli.

have reported sensitivity of this method in respect of DVT as $89-100 \%$ and specificity as $94-100 \%[2,6,10]$.

Studies show variations in the area examined by CTV. Some have examined the areas below the diaphragm as far as the popliteal area [2], while others have restricted the examination to between the iliac crest and the popliteal area [6]. In a study by Nchimi et al. of 1408 patients investigating the most frequent location of DVT, image slices were taken from the calf veins as far as the level of the diaphragm. Deep vein thrombosis was found below the knee
Tab. IV. Computed tomography venography and color Doppler ultrasonography results of patients in respect of deep vein thrombosis

\begin{tabular}{ccccc} 
& \multicolumn{3}{c}{ CDUS } \\
\cline { 3 - 4 } CTV & \multicolumn{2}{c}{ DVT (+) } & DVT (-) & \\
\cline { 2 - 4 } & DVT (+) & $9(60 \%)$ & $6(40 \%)$ & $15(19 \%)$ \\
\cline { 2 - 5 } & DVT (-) & 0 & 65 & $65(81 \%)$ \\
\hline
\end{tabular}

Figures show the number of patients.

CTV - computed tomography venography, DVT - deep vein thrombosis, CDUS color Doppler ultrasonography

Tab. V. Efficiency of the computed tomography venography test compared to color Doppler ultrasonography in the diagnosis of deep vein thrombosis

\begin{tabular}{l}
\hline Sensitivity: $100 \%$ \\
\hline Specificity: $91 \%$ \\
\hline Accuracy: $92.5 \%$ \\
\hline Positive predictive value: $60 \%$ \\
\hline Negative predictive value: $100 \%$ \\
\hline Likelihood of giving true positive: 11.1 \\
\hline Likelihood of giving true negative: 0 \\
\hline
\end{tabular}

Tab. VI. Computed tomography venography and pulmonary computed tomography angiography results

\begin{tabular}{ccccc} 
& & \multicolumn{2}{c}{ Pulmonary CTA } \\
\cline { 3 - 4 } CTV & PVE (+) & PE (-) & \\
\cline { 2 - 5 } & DVT (+) & 11 & 4 & 15 \\
\hline & DVT (-) & 8 & 57 & 65 \\
\hline
\end{tabular}

Figures show number of cases.

CTV - computed tomography venography, CTA - computed tomography angiography, PE - pulmonary embolism, DVT - deep vein thrombosis

in $48 \%$ of cases, between the knee and inguinal ligament in $36 \%$, and above the inguinal ligament in only $15 \%$.

From the results of the studies, it was reported that the optimal CTV test should include the area from the calf veins to the iliac crest [11]. We realized that the areas of poten-

Tab. VII. Deep vein thrombosis location in the computed tomography venography and color Doppler ultrasonography examinations

\begin{tabular}{lcccc} 
& \multicolumn{3}{c}{ CTV } & \multicolumn{2}{c}{ CDUS } \\
\cline { 2 - 5 } Pelvic & Right & Left & Right & Left \\
\hline Above-the-knee & $1,8,9$ & 9 & $1,(8),(9)$ & (9) \\
\hline Popliteal & $1,5,6,7,8,10,11,14,15$ & $2,3,4,7$ & $1,(4),(5),(6),(7), 8,10,11,14,15$ & $2,3,(4),(7)$ \\
\hline Crural & $1,4,5,12,14$ & $2,10,13$ & $1,(6), 8,14$ & $2,10,(13)$ \\
\hline
\end{tabular}

The data of 15 patients diagnosed with DVT from CTV and/or CDUS. The patients were given a number from 1 to 15 . Figures in parentheses 0 indicate patients with a negative CDUS examination result.

CTV - computed tomography venography, CDUS - color Doppler ultrasonography 
Tab. VIII. Pathologies other than pulmonary embolism on pulmonary computed tomography angiography

\begin{tabular}{lc} 
Pathology & Patient number \\
Pulmonary infarct & 7 \\
\hline Pneumonia & 8 \\
\hline Mediastinal finding* & 16 \\
\hline Congestive cardiac failure/cardiomegaly $^{*}$ & 16 \\
\hline COPD & 21
\end{tabular}

\begin{tabular}{ll}
\hline Pleural effusion & 26 \\
\hline Additional findings $^{\star *}$ & 35 \\
\hline
\end{tabular}

*Atherosclerotic changes in the aorta, presence of lymph node, mass lesion **Atelectasis, sequelae changes, mass lesion, metastasis, emphysema COPD - chronic obstructive pulmonary disease

tial DVT in the veins of the deep calf and pelvic area were not examined in routine CDUS applications, so these areas were included in the current study. Thus, iliac vein thrombus was observed in 2 patients with CTV, which had not been determined in CDUS. When other studies in the literature were examined, the first study was seen to be that of Loud et al. in 1998 [8]. That study was conducted on only 5 patients. In 2 patients with PE observed together with DVT, thrombus was seen on both CTV and CDUS. Opaque appearance of the veins could be achieved at an adequate level in 4 patients. They observed that the application of CTV additional to routine CDUS provided information related to pelvic and abdominal veins.

There are 2 studies which can provide examples on this point. The first is a study by Cham et al. [12] of 541 cases with suspected PE. Pulmonary CTA and CTV images were obtained from 7 separate centers using 4 different CT machines with the same parameters. Although CTV was applied to all the patients at the same time, 116 patients were evaluated with CDUS within 1 week. Deep vein thrombosis was determined in 45 (8\%) patients and PE in 91 (17\%) patients. While PE was not observed in 16 of the patients diagnosed with DVT from CTV, early diagnosis allowed for the application of appropriate treatment. Thus a result was reached of a $16 \%$ increase in thromboembolism diagnosis with CTV. Of the patients who underwent CDUS examination, 15 (13\%) were examined with both imaging methods. In 4 patients, DVT diagnosis was made from only CTV examination. The observed DVT locations reported were similar to those of the current study. According to the results of the current study, the CTV test provided early diagnosis and possibility of treatment, particularly in the patient group where DVT was determined but PE had not been determined. Thus in the current study, early diagnosis and a start to treatment was provided for 4 (17\%) patients.

The other series was published by Loud et al. [2]. In a study of 650 patients, CDUS could be applied to 308 patients. Pulmonary embolism, DVT or both were found in $8 \%$ of patients. Pulmonary embolism only was determined in $4 \%$ of patients and DVT only in $5 \%$. As a result of correlation of CDUS of patients, CTV was found to have $97 \%$ sensitivity and $100 \%$ specificity. A wrong negative result was found with CTV in the main femoral vein and the superficial femoral vein in 2 patients with PE. When the distribution of DVT determined with CTV was examined, the fewest findings (17\%) were determined in the iliac vein and its proximity.

Of these, isolated thrombus was observed in the iliac vein and/or the inferior vena cava in 3 patients with PE. In conclusion, it was reported that the CTV test was effective in the determination of thrombus in the lower extremity, particularly in the pelvic and abdominal veins. In the current study, DVT was observed with CTV in the pelvic veins in 3 patients, whereas DVT was seen with CDUS in only 1 patient. When these 2 extensive series were compared with the current study, the distribution of DVT location was similar. The general conclusion of these 3 studies was that CDUS is insufficient in the pelvic veins.

Some researchers have reported that as the sensitivity and specificity of CTV have been found to be low in the determination of DVT, CDUS examination may be an alternative. In a study by Garcia-Bolado et al., CTV sensitivity was found to be $58.8 \%$, specificity $95 \%$, positive predictive value $66.7 \%$ and negative predictive value $93.2 \%$. Supporting these results, it was reported that CDUS should be selected for patients thought to have a diagnosis of DVT [13]. In a retrospective study by Peterson et al. [14], CTV sensitivity was found to be $71 \%$, specificity $93 \%$, positive predictive value $53 \%$ and negative predictive value $97 \%$. In that study of 137 patients, diagnosis of DVT was made with CTV in 10 patients and with CDUS in 8 patients. As CDUS is more advantageous in terms of costs while the CTV test was sensitive but not specific and the positive predictive value was low, they stated that CDUS should be preferred for suspected DVT.

In the current study, thrombus was determined with CTV in $18 \%$ of patients. In the literature, this rate varies from 8 to 19\%. The reason for the higher rate of DVT observed with CTV may be that the patients of the current study were selected by evaluation of the Chest Diseases Department. In addition, 4 patients were determined with DVT on CTV but PE was not seen on pulmonary CTA, which was found to contribute $0.5 \%$ to the rate of thromboembolic disease diagnosis of CTV. In the literature this rate varies from $2 \%$ to $4.3 \%$.

The current study has some limitations. Although conventional angiography is known to be the gold standard in the diagnosis of DVT, its use is restricted nowadays as it is an invasive method. Therefore, as in previous similar studies, CDUS was accepted as the gold standard as it is known to have high accuracy and diagnostic value in the determination of DVT. The radiation dose received by the patients was not calculated in this study. However, previous studies in the literature have reported dosage values in a normal extremity CT examination not to be excessive, varying from 7.25 to $8.26 \mathrm{mSV}$. As these values are at an acceptable level, no separate radiation dose calculation was made. 


\section{Conclusions}

The CTV test performed after pulmonary CTA has high diagnostic value in the determination of DVT. Computed tomography venography is a rapid imaging method which can be an alternative to CDUS, particularly in some cases where CDUS application and evaluation remain insufficient.

\section{Disclosure}

Authors report no conflict of interest.

\section{References}

1. Dalen JE, Alpert JS. Natural history of pulmonary embolism. Prog Cardiovasc Surg 1975; 17: 259-270.

2. Loud PA, Katz DS, Klippenstein DL, Shah RD, Grossman ZD. Combined CT venography and pulmonary angiography in suspected thromboembolic disease: diagnostic accuracy for deep venous evaluation. AJR 2000; 174: 61-65.

3. Kearon C, Julian JA, Newman TE. Noninvasive diagnosis of deep venous trombosis. Ann Intern Med 1998; 128: 663-668.

4. David BP, Michael AR. Vascular ultrasound. The Surgical Clinics of North America 1998; 48: 273-281.

5. Task Force report. European Society of Cardiology. Guidelines on diagnosis and management of acute pulmonary embolism. Eur Heart J 2000; 21: 1302-1336.

6. Duwe KM, Shiau M, Budorick NE, Austin JHM, Berkmen YM. Evaluation of the lower extremity veins in patients with suspected pulmonary embolism: a retrospective comparison of helical CT venography and sonography. AJR 2000; 175: 1525-1531.

7. Moser KM. Venous thromboembolism. Sate of the art. Am Rev Respir Dis 1990; 141: 235-249.

8. Loud PA, Grossman ZD, Klippenstein DL, Ray CE. Combined CT venography and pulmonary angiography: a new diagnostic technique for suspected thromboembolic disease. AJR 1998; 170: 951-954.

9. Dodd JD. Evidence-based Practice in Radiology: Steps 3 and 4 - Appraise and Apply Diagnostic Radiology Literature. Radiology 2007; 242: 342-354.

10. Garg K, Kemp JL, Wojcik D, Hoehn S, Johnston RJ, Macey LC, Baron AE. Thromboembolic disease: comparison of combined CT pulmonary angiography and venography with bilateral leg sonography in 70 patients. AJR 2000; 175: 997-1001.

11. Nchimi A, Ghaye B, Noukoua CT, Dondelinger RF. Incidence and distribution of lower extremity deep venous thrombosis at indirect computed tomography venography in patients suspected of pulmonary embolism. Thromb Haemost 2007; 97: 566-572.

12. Cham MD, Yankelevitz DF, Shaham D, Shah AA, Sherman L, Lewis A, Rademaker J, Pearson G, Choi J, Wolff W, Prabhu PM, Galanski M, Clark RA, Sostman HD, Henschke $\mathrm{Cl}$. Deep venous thrombosis: detection by using indirect CT venography. Radiology 2000; 216: 744-751.

13. Garcia-Bolado A, Del Cura JL. CT venography vs ultrasound in the diagnosis of thromboembolic disease in patients with clinical suspicion of pulmonary embolism. Emerg Radiol 2007; 14: 403-409.

14. Peterson DA, Kazerooni EA, Wakefield TW, Knipp BS, Forauer AR, Bailey BJ, Sullivan VV, Proctor MC, Henke PK, Greenfield LJ, Stanley JC, Upchurch GR Jr. Computed tomographic venography is specific but not sensitive for diagnosis of acute lower-extremity deep venous thrombosis in patients with suspected pulmonary embolus. J Vasc Surg 2001; 34: 798-804. 